\title{
Handling Digital Divide among Students in Nigerian Tertiary Institutions: A Discourse
}

\author{
Sunday O. Onwe ${ }^{1} \&$ Emmanuel A. Ezekwe ${ }^{1}$ \\ ${ }^{1}$ Department of Public Administration, Ebonyi State University, Abakaliki, Nigeria \\ Correspondence: Emmanuel A. Ezekwe, Department of Public Administration, Ebonyi State University, \\ Abakaliki, Nigeria. E-mail: emmadosky@yahoo.com
}

Received: February 1, 2014 Accepted: March 14, 2014 Online Published: April 29, 2014

doi:10.5539/par.v3n1p98 URL: http://dx.doi.org/10.5539/par.v3n1p98

\begin{abstract}
The use of ICT in tertiary institutions for learning, researching, teaching and community development is an ongoing reality in $21^{\text {st }}$ century. However, the inequalities that exist among tertiary students are the source of a significant anxiety. Such inequalities need to be detected and addressed and therefore close the digital divide. This qualitative study discusses the digital divide among Students by using ICT access/skills and inadequate ICT facilities in tertiary institutions. Results obtained revealed that there is presence of digital divide in the tertiary institutions environment. Such inequalities with respect to technology imply inadequate ICT resources available and difficult to access the facilities. It is noteworthy that the fact that not all tertiary students use ICT in carrying out their research and sources bibliography for academic purposes, but they use such ICT facilities more frequently for social/personal gains.
\end{abstract}

Keywords: digital divide, ICT, facilities, students, tertiary institutions, ICT knowledge and usage

\section{Introduction}

The assumption that the new generation of ICT's inequality among students in our tertiary institutions has attracted widespread attention and prompted debate among professionals and the research community. Digital divide Researchers into ICTs as found at the different educational levels, is derived from innovative experiences and highlights the relevance of ICTs for collection and dissemination of information, communications within the educational community, online collaboration, etc. Cavusa and Kanbulb (2010) indicated some of the advantages of using e-learning platforms such as for sending and receiving works/exercises, providing immediate feedback in tests, communicating with teachers and other colleagues, accessing training information and carrying out collaborative work. Other authors pointed to the importance of ICTs to follow-up learning, develop communications and plan the teaching process (Cavus, 2010; Lonn \& Teasley, 2009; cited by Ricoy, Feliz, \& Couto, 2013).

Greater percentage of the students secured admissions in the tertiary institutions with inadequate ICT access/competence of using technology. Other challenges are considered like skills and confidence Economic viability and Inadequate ICT facilities as some struggle to participate fully in the learning practice may be a nightmare. Bridging the digital divide is not the responsibility of individual students, and the curriculum may not be designed to address these concerns. It is the responsibilities of tertiary institutions top management and students to fashion out ways of improving the needed ICT facilities for the overall academic performance. The study of Baume (1996) conducted on the field asserted that the social and educational climate is creating a paradoxical situation for many lecturers, who need to become lifelong learners themselves in order to facilitate the learning of others. Formal staff development and continuing professional development in British universities is a relatively new phenomenon and often regarded with skepticism. What the situation may be in western world may be different in the Nigerian tertiary system; the efforts of some developmental partners in area of manpower development and training have not yielded desired output as a result of inadequate input and inconsistency.

The effective maintenance in the tertiary institution is capital intensive. In most cases the cost of initial installation of an efficient ICT system exceeds the budget of the tertiary institutions and as a result tertiary institutions require external assistance to adopt the appropriate ICT facilities. Though tertiary education trust fund (tetfund) through National Universities Commission (NUC) has assisted most universities in to acquire ICT facilities, the assistance has not been sufficient enough to enable the Universities meet the international standard 
ratio of one user to one system (1:1), Dunleavy, Dextert \& Heinecket (2007). The funding constraint has remained a significant challenge to adoption and usage of ICT facilities in the tertiary institution system. ICT's upgrades, in most time are quickly in response to commercial social drivers. It is almost impossible for busy students to stay up to date with all the latest developments. For the 'net generation', technology choices are an aspect of lifestyle and identity. There are challenges for everyone involved in student learning to support the diversity of chosen devices and ways of working. Institutions are increasingly judged on the quality of the student experience, and Inadequate ICT facilities are scrutinized closely by prospective students and their parents. However, resources of digital know-how and expertise are less visible and are less obvious targets for investment (Supporting Learners in a Digital Age, 2011). Given what obtains elsewhere, it has become obvious that ICT facilities are available and affordable, to enhance creative output and social networking development of the teaming students.

The implementation and usage of ICT facilities require regular power supply. The Nigeria nation state is characterized with irregular power supply for which the Tertiary institutions system is part of. Electricity power fluctuations have negative effect in ICT adoption and usage as it affects free and timely flow of information. Given the economic conditions of the Nigerian academic/students the use of generating sets as alternative power supply becomes too expensive to be constantly maintained for ICT usage. To the extent power supply is irregular many ICT facilities in the Nigerian Tertiary institutions system do not offer twenty four (24) hours service to the academic staff and students who need them at all times for teaching, learning, and research. The limited usage of ICT facilities orchestrated by irregular power supply and its concomitant destruction of some of the ICT facilities has made many a user of ICT facilities reluctant to visit and use facilities in the tertiary institutions. To this end Nigerian Tertiary institutions is culpable. In studies conducted by Ricoy, Feliz \& Couto (2013), observed that an analysis that the available ICT resources, their usefulness and the training needs of students can provide important information to teachers, the scientific community, institutions and politicians. Of special interest to the development of the training process, is the adaptation of methodological strategies to incorporate ICTs, in order to respond to the expectations and demands of contemporary society. One of the greatest challenges to ICT is positive attitude to change, whether it's a change of job, or pedagogy, a change in a relationship, or a change in economic status. Considering the benefits of adopting ICT a 'whatever-it takes' attitude when confronted by technology innovation. ICT provides new opportunities to explore high cognitive activities such as, autonomy, creativity, problem solving and teamwork. It equally provides with the means to take into account individual needs of students especially, while using web based technology, Aduke (2008).

However, considering the Nigerian tertiary institutions students environment and the educational curriculum, adopting ICT for teaching, learning, research and community development to a reasonable extent has paved way for digital divide and affect the academic performance or creative output.

\section{ICT Theory}

This study is anchored on technological determinism theory. The technological determinism theory according to Lievrouw and Livingstone (2006) is of the belief that ICT's have an overwhelming power to drive human actions socially, economically, as well as production and development. These are points emphasized in this study as the study sees the use of ICTs to bring about changes that would lead to sustainable development in Nigerian tertiary institutions. If quality of students and high productivity are to be achieved and sustained as being clamoured for by the National Universities Commission (NUC), it will be relevant for NUC quality assurance programme of Nigerian Universities. Thus the government, people and ICTs, are vital tools in this regard.

All these issues are part of the tenets of technological determinism theory, and will be exhaustively explored in this study. Apparently, the relevance of technological determinism theory to this study is indisputable as it provides the springboard on which the study rests upon. In essence, technological determinism theory presupposes that the ability of the organizations to face environmental challenges and progress depends largely on the extent such organizations embrace ICT.

The knowledge of the theory will assist the policy makers, various stakeholders and professionals to be better equipped in bridging the digital divide and encourage the students to have the Inadequate ICT facilities to encourage them on ICT skills and secure global competitive advantage. It is assumed that every practice is anchored on theory, it is important that digital divide in Tertiary institutions, Nigerian be closed through manpower development training and curriculum redesign.

\section{The Concepts of Digital Divide}

Inadequate ICT facilities such as telephones, personal computers, and the internet are increasingly critical to economic development and personal advancement. There is a gap separating the world's information "Have" and 
"Have nots" which is what is now mostly called the digital divide - the divide between those with access to new info-communications technologies and those without. The initiation of ICT for example has been variously seen as being important for students and the society as the socio-economic development in areas of research and community development. It is worrisome to inform who have not used the ICT facilities how it has the potentials to change lives, to create social networks, new business or facilitate easy delivery of courses during lectures in the classrooms. Digital divide is fundamentally about social differences and similarities in usage of Inadequate ICT facilities. In work done by UNESCO (2008), digital competence comprises mastery of the several capacities of students to search, select, analyze and evaluate information rather than just technical operation of technological equipment. This means that they must be creative and efficient at using digital tools, communicate and collaborate with other people, and produce and publish materials and information. They must also be able to solve problems, make decisions through technology, be responsible and contribute to enriching the knowledge society. However, it is conceptualized that digital divide centres on inequality to access ICT facilities when needed or as a result technical incompetence. In study conducted by The Organization for Economic Co-Operation and Development (OECD, 2001) defines the concept of "Digital Divide" as the inequality of access to ICTs among geographic areas and people from different socio-economic levels.

Digital divide is a problem that influences academic staff/students across the globe to a reasonable extent. The inventors, researchers and scientists have tried to analyze the concepts at different levels of developments among academic staff/student's life in an attempt to realize the fundamental problems and give answers and possible solutions. The study of Waycott \& Bennett, Kennedy, Dalgarno and Gray (2010) identified differences in the use of technology in higher education and in the daily lives of teachers and students in Australia. They justified such differences based on individual motivations and social norms that promote the use of ICTs. The study revealed that teachers are the ones who most resist use of ICTs as against students who are receptive and enthusiastic. The study also showed that teachers mostly focused on using ICTs for institutional matters and pedagogic application while students use the same to organize their social life.

The Digital Divide problem is complex and lacks an easy solution. Simply put, the Digital Divide refers to a significant difference in the access to and equity of technology experience based on categories such as income, race, gender, location, or education. It is easy to have conversations about why there is a Digital Divide, the need for more funding, and the creation of ideal learning environments. What is problematic is finding practical and workable solutions for classroom teachers. Yet there are some beginning steps that all teachers can take. (Pearson \& Swain 2001). Thus to a great extent extra-curriculum activities is needed for both academic staff/students for continuous practice and training in computer departmental laboratory or ICT's service providers within the environment to encourage high level of competence using the ICT's facilities. See below the detail internet usage in Africa and worldwide, 2009, for better understanding of the concepts under discussion.

Table 1. Internet usage in Africa and Worldwide 2009

\begin{tabular}{cccccc}
\hline Region & $\begin{array}{c}\text { Population } \\
(2009, \text { Est. })\end{array}$ & $\begin{array}{c}\text { Share of world } \\
\text { population }\end{array}$ & $\begin{array}{c}\text { Internet users } \\
\text { March, 2006 }\end{array}$ & $\begin{array}{c}\text { Internet penetration } \\
\text { (\% penetration) }\end{array}$ & $\begin{array}{c}\text { \% User's in } \\
\text { world }\end{array}$ \\
\hline $\begin{array}{c}\text { Total of } \\
\text { Africa }\end{array}$ & $991,002,342$ & $14.6 \%$ & $67,371,700$ & $6.8 \%$ & $3.9 \%$ \\
$\begin{array}{c}\text { Rest of the } \\
\text { world }\end{array}$ & $5,776,802,866$ & $85.4 \%$ & $1,666,622,041$ & $28.9 \%$ & $96.1 \%$ \\
$\begin{array}{c}\text { World } \\
\text { total }\end{array}$ & $6,767,805,208$ & $100.0 \%$ & $1,733,993,741$ & $25.6 \%$ & $100.0 \%$ \\
\hline
\end{tabular}

Source: Internet World Statistics: http://www.internetworldstats.com

The table 1, above depict the digital divide is a serious problem in most African countries and Nigeria nation state is characterized inadequate or paucity of information society facilties around the globe. To support the assumption, Nigeria has made an effort in salvaging the digital divide in the country which tertiary institutions is included through the Ministry information \& Technology, though such needed effort is yet to give appropriate output in the system. Almost African countries including Nigeria often have economic challenges especially in the take off and continued sustainability of the facilities. The communication satellite and ICT facilities are capital intensive and needs more funds and adequate time to realize its philosophy and objectives. Thus, indeed, 
is a challenge to contend with and may require the technical capacity/appropriate technology and external assistance to increase the availability and usage among tertiary institutions students in the country.

\section{Schools, Universities Access Program to Digital Life Style}

The programme was designed to provide broadband connectivity to schools and universities and neighboring communities. USPF says that its Schools Access Project has been rolled out to 766 government schools representing $41 \%$ achievement of 1,858 schools targeted under its School Access Project (SAP) aimed at providing public schools with ICT hardware and funding subscriptions for broadband internet for at least one year. In addition, USPF also said TiAP has been rolled out to 193 tertiary institutions across the country targeting 374 tertiary institutions under the Tertiary Institution Access Project (TiAP) to provide tertiary institutions with ICT hardware and funding subscription for broadband internet for at least one year.

Meanwhile the Fund's e-Library project has been deployed to 74 libraries across the country under the project to provide internet connections to public libraries and institutions in underserved/ un-served areas across the country, USPF says. USPF says that SAP has been rolled out to 766 government schools representing $41 \%$ achievement of 1,858 schools targeted under its School Access Project (SAP) aimed at providing public schools with ICT hardware and funding subscriptions for broadband internet for at least one year, (Strategies for the promotion of broadband services and infrastructure: A case study on Nigeria, September 2012). Therefore, going by the intended policies and plan the effort are yet to meet the significant percentage of teaming population of students in Nigerian tertiary institution. Nigeria has witnessed appointment into key areas of concern are done not merit or expertise knowledge in the field but on political considerations and needed not be politicized. The menace of political influence within the nation along partisan politics remains discouraging in Nigeria's quest in bridging the digital divide.

\section{Digital Divide in Education}

Perhaps, Nigerian universities are not highly ranked in world tertiary institutions ranking because most revered Professors and senior academic members seem not to be ICT knowledgeable as a result their results output are not properly documented and disseminated. Not only that they are not knowledgeable in ICT usage the universities' ICT centres have not found it necessary to constantly upgrade their portal thereby providing obscure information to their users.

The few Universities that have ICT facilities do not have insufficient modern telecommunication facilities that enable both the staff and students to access their e-mail, social networks, search engines at will or when necessary. This affects the extent the Tertiary institutions communities do network within environment and other Universities around the globe; as well reduces the extent of publications, research, teaching and learning as ICT aided learning is seriously played down.

Related to the issue of insufficient allocation of fund is the problem of irregular power supply. ICT facilities need regular power supply for regular usage. In a situation where power supply is irregular, the cost of using ICT facilities increases, especially as premium motor spirits (PMS) and generating sets require huge amount of money to be provided. Not all the students or let alone the student can afford to procure PMS for some of them that have the facilities.

Again, majority of academic staff/students in Nigerian Universities rely heavily on manual and traditional practices of searching bibliographies, abstracts and other published works. With this approach the appreciation of ICT and its usage is played-down. ICT usage is not given the priority that it deserves thereby making ICT knowledge and usage difficult; competence in its usage is thereby jeopardized. Consequently, the paucity of technical competence is one of the greatest challenges facing the Nigerian Tertiary institutions community.

In addition, in a review of previous studies of computer anxiety, or what may be called digital divide was conducted by Selwyn (1997) cited in Preston, Cox \& Cox (1999), found that a major deterrent to the use of computers by teachers was computer phobia. These teacher anxieties could be caused by:

- $\quad$ psychological factors such as having little or no control over the activity, thinking that they might damage the computer, and feeling that one's self esteem is threatened;

- $\quad$ sociological factors such as ICT being regarded as a solitary activity, needing to be clever to use one, and being replaced by the computer;

- $\quad$ operational factors such as being beyond one's abilities, having to cope with unfriendly jargon, and the likelihood of the technology going wrong.

These factors highlighted are catalyst for digital divide among students in Nigerian tertiary institutions. 


\section{Closing Digital Divide through Manpower Training}

Closing the digital divide in Nigerian Tertiary institutions is necessary because it will enhance learning opportunities for students and increase their ICT skills. The study of Lowry (1997) confirmed that it is often observed that the diffusion of new innovations is along and timely process and must recognize that the use of ICT in a classroom is an innovation. Thus students may be provided with long time manpower training and adequately procure ICT facilities for the continued practice within the school system and outside the school. The ICT facilities need a great change in teaching methodology that will not take place suddenly. The role of Tertiary institutions management must be put into consideration and environmental dispositions, their readiness for affordability of ICT infrastructure, high quality of pedagogy and high moral justification to dispense the needed for the students without sacrificing such at the altar of bribery and corruption.

Therefore, it is pertinent to encourage the students of Nigerian tertiary institutions on manpower training and developments as well encourage the economic policy instrument to improve the ICT facilities to ensure equal access and usage. If a good policy is adopted the present and future of the students will develop an efficient academic curriculum, research and community development that will be at the apogee of excellence in the global community and produce competent graduates.

Closing the gap the ICT skills and competences is highly needed, this is because the staff may be economical viable and ICT facilities is available and affordable but the access/skills and the humanware is not playing, the problem is not solved. The students need to be trained and students to use ICT facilities as a teaching, learning and research, networking tool and problem solving. Lifelong learning practices if encouraged among students and students thereby giving them extra-curriculum activities to accommodate ICT learning and practice at the various tertiary institutions computer laboratories is highly solicited in this $21^{\text {st }}$ century. Sahin (2006) believes that there is a possibility that an individual may have all the necessary knowledge (awareness about the existence of an ICT) and yet refuse to adopt and use it consequent upon relational and environmental factors. However, in most cases peers and colleagues do persuade an individual, institutions or organizations to either adopt or reject an innovation. The decision to do so is usually seen as closing the gap.

It is the assumption of the researcher that the students if trained may be disposed to examine the relevant/needed software and how they are using software packages and determine whether the software is meeting the needs of the system. If the only experience researcher has technology is loading and using a game programs, the question that will exist is are we adopting technology to its full potential with all academic staff/students. The relevant packages like statistical software should be taught to enable them posses the research knowledge on the need of the analysis of data gathered. Indeed, innovation is expressed and adopted based on time, place and space because an innovative idea in a particular geographical location at a particular period may be an obsolete idea in another place given time and space.

In addition, this systems approach recognizes that while learning occurs within the individual, it takes place within a social context which makes social interaction central to the learning process (Anderson, 2003; Holmes et al., 2001; Grabinger \& Dunlap, 2000; Cormier, 2008). Assumptions about the role of social interaction arising from tacit learning relationships need to be made explicit when designing effective ICT enabled learning environments. The concept of learning relationships (Fowler \& Mayes, 2000) drawing upon insights gained from psychology and anthropology about situated learning can provide an example of a theoretical framework which implements a technology of education approach in the design of learning environments which effectively incorporate ICTs. Fowler and Mayes (2000) define the concept of a learning relationship as inherently a social one in that we learn from and through others. (Samarawickrema, 2008). To support the assertion, manpower training in any social organization is a catalyst for success/failure, because the economic viability and ICT facility depends greatly on manpower to close the digital divide.

The study of Goode (2010) cited in Ricoy, C. Feliz, T. \& Couto, M. J. (2013), highlights about the high costs of technologies and states that students who do not have enough resources and experience would probably lose out on training opportunities. Such findings correlate the situation the tertiary institutions students found themselves, from the study since they do not possess the ICT competences required to use the facilities, manpower development training and adequate provision of ICT facilities are one of the strategy to close the digital divide in the system.

According to structurational theorists, technologies are intended to allow equal opportunities for users. DeSanctis and Poole (1994), they asserted that the outcomes described above as a form of ironic appropriation. For instance, those members of society already at 'have not' from participation in much of society resource and opportunities, such as those at the low end of the income spectrum, are being out from improving their situations because they 
are completely out from opportunities to change society's rules and resources. Thus it is an assumption that ICT defines society and anyone outside the context in $21^{\text {st }}$ century is outside the society; on the contrary anyone within the context is in the society and such individual/group is closing the gap.

\section{Conclusion}

The digital divide not only affects students s' access to institutional resources, but also affects their opportunities to use ICT facilities. In addition the few students that have the access make use of ICT facilities mostly for their personal gains, social networks chats and not for academic performance.

\section{References}

Aduke A. F. (2008). Usage of challenges of Information and Communication Technology (ICT) in teaching and learning in Nigerian Universities. Asian Journal of Information and Technology, 7(7), 290-295.

Anderson, D. M. (2003). Cautious Optimism about Online Politics and Citizenship. In D. M. Anderson, \& M. Cornfield (Eds.), The Civic Web (pp. 19-34). New York: Rowman \& Littlefield.

Baume, D. (1996). Editorial International Journal for Academic Development. Journal of the International Consortium foe Educational Development, 1(1), 1-5.

Cavus, N. (2010). The evaluation of learning management systems using an artificial intelligence fuzzy logic algorithm. Advances in Engineering Software, 41(2), 248-254. http://dx.doi.org/10.1016/j.advengsoft. 2009.07.009

Cavusa, N., \& Kanbulb, S. (2010). Designation of Web 2.0 tools expected by the students on technology-based learning environment. Procedia Social and Behavioral Sciences, 2, 5824-5829. http://dx.doi.org/10.1016/j.sbspro.2010.03.950

Cormier, D. (2008). Rhizomatic education: Community as curriculum. Innovate, 4(5).

DeSanctis, G., \& Poole, M. S. (1994). Capturing the Complexity in Advanced Technology Use: Adaptive Structuration Theory. Organization Science, 5, 121-147. http://dx.doi.org/10.1287/orsc.5.2.121

Dunleavy, M., Dextert, \& Heinecket. (2007). What added value does a 1:1 student to laptop ratio bring to technology-supported teaching and learning? Journal of computer assisted leaning, 23, 440-452.

Epstein, D., Nisbet, E. C., \& Gillespie, T. (2011). Who's Responsible for the Digital Divide? Public Perceptions and Policy Implications. The Information Society, 27(2), 92-104. http://dx.doi.org/10.1080/01972243. 2011.548695

Fowler, C. J. H., \& Mayes, T. J. (2000). Learning relationships from theory to design. In D. Squires, G. Conole, \& G. Jacobs (Eds.), The Changing Face of LEARNING TECHNOLOGY. Cardiff: University of Wales Press.

Goode, J. (2010). Mind the gap: The digital dimension of college access. The Journal of Higher Education, 81(5), 583-618. http://dx.doi.org/10.1353/jhe.2010.0005

Grabinger, R., \& Dunlap, J. C. (2000). Rich environments for active learning: A definition. In D. Squires, G. Conole, \& G. Jacobs (Eds.), The Changing Face of LEARNING TECHNOLOGY. Cardiff: University of Wales Press.

Holmes, B., Tangney, B., FitzGibbon, A., Savage, T., \& Mehan, S. (2001). Communal Constructivism: Students constructing learning for and with others. Centre for Research in IT in Education, Trinity College. Dublin: Ireland.

Internet World Statistics. (2009). Retrieved March 14, 2014, from http://www.internetworldstats.com

ISC. (2011). Supporting Learners in a Digital Age. Brief paper.

Lievrouw and Livingstone. (2006). Technological determinism theory: A test of construct validity. Computers and Nursing, 14(3), 164-170.

Lonn, S., \& Teasley, S. D. (2009). Saving time or innovating practice: Investigating perceptions and uses of learning management systems. Computers \& Education, 53(3), 686-694. http://dx.doi.org/10.1016/j. compedu.2009.04.008

Lowry. (1997). Supporting adoption of Innovations. Kappa Delta Records, 34, 10-13. 
O’Sullivan, M. L., \& Samarawickrema, G. (2008). Changing learning and teaching relationships in the educational technology landscape. In Hello! Where are you in the landscape of educational technology? Proceedings ascilite Melbourne 2008.

OECD. (2001). Understanding the digital divide. Paris: Organisation for Economic Co-operation and Development.

Pearson T., \& Swain, C. (2001). Bridging the digital divide: A building block for teachers. International Society for Technology in Education, 28(8).

Preston, C., \& Cox. (1999). What Motivates Teachers to Use ICT? Paper presented at the British Educational Research Association Annual Conference, University of Sussex at Brighton, September 2-5, 1999.

Ricoy, C., Feliz, T., \& Couto, M. J. (2013). The digital divide among University Freshmen. TOJET: The Turkish Online Journal of Educational Technology, 12(2).

Sahin, I. (2006). Detailed review of Roger's diffusion of innovations theory and educational technology. The Turkish Online Journal of Educational Technology, 5(2), 14-23.

Selwyn, N. (1997). Teaching Information Technology to the 'Computer Shy': A theoretical perspective on a practical problem. Journal of vocational education and training, 10(3), 395-408. http://dx.doi.org/ $10.1080 / 13636829700200023$

Selwyn, N. (2004). Reconsidering political and popular understanding of the digital divide. New Media and Society, 6(3), 341-362. http://dx.doi.org/10.1177/1461444804042519

Strategies for the promotion of broadband services and infrastructure. (2012). A case study on Nigeria. .

UNESCO. (2008). ICT competency standards for teachers.

Waycott, J., Bennett, S., Kennedy, G., Dalgarno, B., \& Gray, K. (2010). Digital divides? Student and staff perceptions of information and communication technologies. Computers \& Education, 54(4), 1202-1211. http://dx.doi.org/10.1016/j.compedu.2009.11.006

\section{Copyrights}

Copyright for this article is retained by the author(s), with first publication rights granted to the journal.

This is an open-access article distributed under the terms and conditions of the Creative Commons Attribution license (http://creativecommons.org/licenses/by/3.0/). 